\title{
Rhodopseudomonas rhenobacensis sp. nov., a new nitrate-reducing purple non-sulfur bacterium
}

\author{
Angela Hougardy, ${ }^{1}$ B. J. Tindall ${ }^{2}$ and Jobst-H. Klemme ${ }^{1}$
}

Author for correspondence: Jobst-H. Klemme. Tel: +49 228735590 . Fax: +49228737576. e-mail: jh.klemme@uni-bonn.de

1 Institut für Mikrobiologie \& Biotechnologie, Meckenheimer Allee 168, 53115 Bonn, Germany

2 DSMZ, Mascheroder Weg 1b, D-38124 Braunschweig, Germany

\begin{abstract}
During the course of isolating and identifying purple non-sulfur bacteria, one nitrate-reducing strain was isolated which did not fit the description of any other purple non-sulfur bacterium known to date. The isolate had rod-shaped cells that contained lamellar intracytoplasmic membranes and produced red cultures. Absorption maxima of photosynthetically grown cell homogenates were at 376, 471, 503, 540, 591, 805 and $878 \mathrm{~nm}$. The new isolate grew anaerobically in the light or aerobically in the dark. Various organic compounds served as carbon sources and electron donors. The predominant quinone was ubiquinone 10, the predominant fatty acid was 18:1 $\omega 7 \mathrm{c}$. The polar lipids comprised diphosphatidyl glycerol, phosphatidyl glycerol, phosphatidyl ethanolamine and phosphatidyl choline. Analysis of the $16 \mathrm{~S}$ rDNA gene sequences revealed that the new isolate was closely related to Rhodopseudomonas palustris. A DNA-DNA-hybridization study differentiated the new isolate and Rhodopseudomonas palustris at the species level. Therefore, the name Rhodopseudomonas rhenobacensis sp. nov. is proposed for the new isolate.
\end{abstract}

Keywords: Rhodopseudomonas, purple non-sulfur bacteria, 16S rDNA, chemotaxonomy

\section{INTRODUCTION}

The purple non-sulfur bacteria are a versatile group of bacteria that grow anaerobically in the light or aerobically in the dark with different carbon sources, electron donors and nitrogen sources. The capacity to reduce nitrate, either for assimilatory or dissimilatory growth, is not a common feature of this group of bacteria, being restricted to several species. Due to the fact that most work concerning nitrate reduction in purple non-sulfur bacteria is done with Rhodobacter capsulatus and Rhodobacter sphaeroides, we were interested in isolating nitrate-reducing strains not belonging to these two species.

In the course of isolating and identifying nitratereducing purple non-sulfur bacteria we have isolated several strains from eutrophic ponds in the vicinity of Bonn, Germany. One of these strains, belonging to the species Rhodoferax fermentans, was described earlier

Abbreviation: ICM, intracytoplasmic membrane.

The EMBL accession numbers for the 16S rDNA sequence of Rhodopseudomonas rhenobacensis are AJ132401 and AJ132402.
(Hougardy \& Klemme, 1995). In this paper, genotypic and phenotypic characteristics of another isolate are described. We conclude that it should be classified as a new species of the genus Rhodopseudomonas, for which we propose the name Rhodopseudomonas rhenobacensis.

\section{METHODS}

Enrichment and isolation. The samples used for enrichment and isolation of phototrophic bacteria were freshwater samples with sediment mud that were obtained from a eutrophic pond located in a beech forest close to Rheinbach, a small town in the vicinity of Bonn, Germany. Water samples $(50 \mathrm{ml})$ were filtered through membranes (Sartorius; pore size $0.45 \mu \mathrm{m}$ ), which were then incubated anaerobically in the light $\left(28^{\circ} \mathrm{C}\right)$ on agar plates containing the RCV medium described by Weaver et al. (1975) supplemented with $0 \cdot 2 \%$ sodium succinate instead of sodium malate and $0.05 \%$ yeast extract instead of thiamin. $0.05 \% \mathrm{KNO}_{3}$ and $0.5 \mathrm{mM}$ EDTA were also added to the enrichment medium. After $8 \mathrm{~d}$, small red and brown colonies appeared on the membrane filters. Single colonies were picked, streaked on the surface of agar plates, and the resulting new colonies were transferred to liquid media with 
the same composition as before. Pure cultures were achieved by repeated restreaking on agar plates.

Bacterial strains and cultivation. Of 42 isolates one (strain $\mathrm{Rb}^{\mathrm{T}}$ ) was used for further investigation. Rhodopseudomonas palustris DSM $123^{\mathrm{T}}$ was used for comparison. All strains were routinely cultivated under photosynthetic conditions $\left(28{ }^{\circ} \mathrm{C}\right.$, illuminated at $60 \mathrm{~W}$ by tungsten lamps at a distance of $20 \mathrm{~cm}$ ) using the RCV medium described by Weaver et al. (1975) supplemented with $0.05 \%$ yeast extract instead of thiamin. In minimal media, yeast extract was replaced by a vitamin solution (Imhoff \& Trüper, 1991). Aerobic dark cultivation $\left(28^{\circ} \mathrm{C}\right)$ was performed in Erlenmeyer flasks filled to only $10 \%$ of their volume and agitated on a shaker.

Phenotypic characterization. Light-microscopic observations were performed using a ZEISS Axiophot microscope (Carl Zeiss). Electron micrographs for visualization of flagella and intracytoplasmic membranes (ICMs) were kindly provided by Professor Ulrich Fischer (University of Bremen, Germany). Absorption spectra were measured according to the method of Biebl \& Drews (1969). Carbonsource utilization tests were performed in screw-cap tubes containing mineral base medium supplemented with the neutralized, filter-sterilized organic compound (final concentration $20 \mathrm{mM}$ ) as the carbon source. In growth experiments with butyrate as the carbon source, malate was replaced by $10 \mathrm{mM}$ butyrate and $\mathrm{KHCO}_{3}(30 \mathrm{mM})$ was added from filter-sterilized stock solutions. In all growthresponse tests, growth was monitored turbidometrically at $650 \mathrm{~nm}$. Test tubes in which the $\mathrm{OD}_{650}$ after $6 \mathrm{~d}$ was greater than the $\mathrm{OD}_{650}$ of a negative control containing no test substrate were considered positive for growth. $\mathrm{NO}_{2}^{-}$in the culture fluids was determined, after removal of bacterial cells by centrifugation, by colorimetric techniques (Nicholas \& Nason, 1957).

Extraction of respiratory lipoquinones and polar lipids. Respiratory lipoquinones and polar lipids were extracted from $100 \mathrm{mg}$ freeze-dried cell material using the twostage method described by Tindall (1990a, b). Respiratory quinones were extracted using methanol/hexane (Tindall, $1990 \mathrm{a}, \mathrm{b})$ and the polar lipids were extracted by adjusting the remaining methanol $/ 0 \cdot 3 \%$ aqueous $\mathrm{NaCl}$ phase (containing the cell debris) to give a chloroform $/$ methanol $/ 0 \cdot 3 \%$ aqueous $\mathrm{NaCl}$ mixture $(1: 2: 0 \cdot 8$, by vol.). The extraction solvent was stirred overnight and the cell debris pelleted by centrifugation. Polar lipids were recovered into the chloroform phase by adjusting the chloroform/methanol $/ 0.3 \%$ aqueous $\mathrm{NaCl}$ mixture to a ratio of $1: 1: 0 \cdot 9$ (by vol.).

Analysis of respiratory lipoquinones. Respiratory lipoquinones were separated into their different classes (menaquinones and ubiquinones) by TLC on silica gel (MachereyNagel), using hexane/tert-butylmethylether $(9: 1, \mathrm{v} / \mathrm{v})$ as solvent. UV-absorbing bands corresponding to menaquinones or ubiquinones were removed from the plate and further analysed by HPLC. This step was carried out on a LDC Analytical HPLC (Thermo Separation Products) fitted with a reverse-phase column (Macherey-Nagel; RP18; $2 \mathrm{~mm} \times 125 \mathrm{~mm}, 3 \mu \mathrm{m}$ particle size) using methanol as the eluant. Respiratory lipoquinones were detected at $269 \mathrm{~nm}$.

Analysis of polar lipids. Polar lipids were separated by twodimensional silica gel TLC (Macherey-Nagel). The first direction was developed in chloroform/methanol/water $(65: 25: 4$, by vol.) and the second in chloroform/ methanol/acetic acid/water (80:12:15:4, by vol.). Total lipid material and specific functional groups were detected using 5\% dodecamolybdophosphoric acid (total lipids),
Zinzadze reagent (phosphate), ninhydrin (free amino groups), periodate-Schiff ( $\alpha$-glycols), Dragendorff (quaternary nitrogen) and anisaldehyde/sulphuric acid (glycolipids) (Stahl, 1967).

Fatty acid analysis. Fatty acids were analysed as the methyl ester derivatives prepared from $10 \mathrm{mg}$ dry cell material. Cells were subjected to differential hydrolysis in order to detect ester-linked and non-ester-linked (amide bound) fatty acids (B. J. Tindall, unpublished). Fatty acid methyl esters were analysed by GC using a $0 \cdot 2 \mu \mathrm{m} \times 25 \mathrm{~m}$ non-polar capillary column and flame ionization detection. The run conditions were: injection and detector port temperature $300^{\circ} \mathrm{C}$, inlet pressure $60 \mathrm{kPa}$, split ratio $50: 1$, injection volume $1 \mu$, with a temperature program from 130 to $310^{\circ} \mathrm{C}$ at a rate of $4^{\circ} \mathrm{C}$ $\min ^{-1}$

The unambiguous position of double bonds and the presence of hydroxy fatty acids was confirmed by GC-MS. Hydroxy fatty acids were detected by their characteristic fragments at $m / z 103$ for $3-\mathrm{OH}$ fatty acids, and at $m / z M^{+}-59$ for $2-\mathrm{OH}$ fatty acids. The position of double bonds was determined using dimethyl disulfide adducts as described by Nichols et al. (1986).

GC-MS. GC-MS analysis of the fatty acids was carried out using a Finnigan MAT GCQ gas chromatograph-mass spectrometer. The gas chromatograph was equipped with a DB-5 column ( $30 \mathrm{~m} \times 0.22 \mathrm{~mm}$, film thickness $0.25 \mu \mathrm{m})$, and helium, at a linear velocity of $40 \mathrm{~cm} \mathrm{~s}^{-1}$, was used as the carrier gas. Samples $(1 \mu l)$ were injected in the splitless mode and separated using a temperature programme starting at $80^{\circ} \mathrm{C}$ (held for $1 \mathrm{~min}$.) followed by a rise of $10^{\circ} \mathrm{C} \mathrm{min}{ }^{-1}$ to $300{ }^{\circ} \mathrm{C}$. The mass spectrometer was run in the EI mode, with a source temperature of $175^{\circ} \mathrm{C}$ and a transfer line temperature of $275^{\circ} \mathrm{C}$. Samples were run either without derivatization or as the dimethyl disulfide derivatives for detecting the position of double bonds.

DNA base composition and DNA-DNA hybridization. DNA was isolated according to the method described by Visuvanathan (1989) and by chromatography on hydroxyapatite by the procedure of Cashion et al. (1977). The $\mathrm{G}+\mathrm{C}$ content of the DNA was determined by HPLC. DNA-DNA hybridization was carried out according to the method of De Ley et al. (1970) using a Gilford System 2600 spectrophotometer equipped with a Gilford 2527-R thermoprogrammer and plotter. These analyses were conducted by the DSMZ, Braunschweig, Germany.

16S rDNA sequencing and phylogenetic analysis. 16S rDNA fragments that correspond to positions 8-1401 of Escherichia coli 16S rRNA were amplified by PCR from chromosomal DNA and sequenced using the 536f and 515r primers by the primer-extension method. The reactions were analysed with a Pharmacia automated laser fluorescent DNA sequencer (analyses conducted by Werner Arnold, University of Bielefeld, Germany).

The CLUSTAL w program (Thompson et al., 1994) was used for multiple alignment, calculation of evolutionary distance, construction of a neighbour-joining phylogenetic tree and statistical evaluation of the tree topology by bootstrap analysis. Alignment positions including gaps and/or unidentified bases (approx. 7\%) were not taken into consideration for the calculations.

Nucleotide sequence accession numbers. The accession numbers for the sequences used to construct the distance matrix tree are as follows: Bradyrhizobium elkanii, AF081266; Bradyrhizobium japonicum, X66024; Nitrobacter 
winogradskyi (ATCC 25381), L35506; Agromonas oligotropha (JCM 1494), D78366; Rhodopseudomonas palustris (ATCC 17001), D25312; Afipia felis, M65248; Rhodopseudomonas acidophila (strain 7050), M34128; Rhodoplanes elegans (strain AS 130), D25311; Rhodoplanes roseus (strain 941), D25313; Blastochloris viridis (ATCC 19567), D25314; Rhodobium marinum (DSM 2698 ${ }^{\mathrm{T}}$ ), D30790; Rhodobium orientis (strain MB 312 ${ }^{\mathrm{T}}$ ), D30792; Rhodomicrobium vannielii (strain EY 33), M34127; Agrobacterium tumefaciens (DMS 30105), M11223; Rhodospirillum rubrum (ATCC 11170), D30778; Paracoccus denitrificans, X69159; Rhodobacter blasticus (ATCC 33485), D16429; Rhodobacter capsulatus (ATCC 11166), D16428; Rhodopila globiformis (ATCC 7950), M59066.

\section{RESULTS}

\section{Isolation}

We attempted to enrich nitrate-reducing purple nonsulfur bacteria other than Rhodobacter capsulatus or Rhodobacter sphaeroides. To avoid the selection of these fast-growing Rhodobacter species, the medium used for enrichment was supplemented with $0.5 \mathrm{mM}$ EDTA, since most strains of the latter two species are strongly inhibited by EDTA at this concentration (Kern et al., 1992). We successfully isolated 42 strains of purple non-sulfur bacteria. One isolate, strain $\mathrm{Rb}^{\mathrm{T}}$, which was isolated from a eutrophic pond located in the forest of Rheinbach, Germany, is described in this paper.

\section{Morphology and ultrastructure}

Strain $\mathrm{Rb}^{\mathrm{T}}$ had rod-shaped cells that tend to form rosette-like clusters in older cultures as described for Rhodopseudomonas palustris and Rhodopseudomonas viridis. The cells measured $0.4-0.6 \mu \mathrm{m}$ in width and $1.5-2.0 \mu \mathrm{m}$ in length, and were motile by means of a single polar flagellum (Fig. 1). Cell division occurred by budding. Electron microscopy of ultrathin sections revealed the presence of internal membranes of the lamellar type. The cell morphology and ultrastructure are shown in Fig. 2.

\section{Photopigments}

The colour of photosynthetically grown liquid cultures of strain $\mathrm{Rb}^{\mathrm{T}}$ was dark red. Absorption maxima of cell homogenates were at 376, 471, 503, 540, 591, 805 and $878 \mathrm{~nm}$ (Fig. 3), indicating the presence of bacteriochlorophyll $a$ and carotenoids of the normal spirilloxanthin series. Cultures grown aerobically in the dark were colourless.

\section{Physiological characteristics}

Strain $\mathrm{Rb}^{\mathrm{T}}$ was able to grow anaerobically in the light or aerobically in the dark. The following organic compounds served as carbon sources: formate, acetate, butyrate, pyruvate, lactate, malate, succinate, fumarate, tartrate, gluconate and ethanol. No growth occurred with citrate, benzoate, propionate, glucose, fructose and methanol (Table 1). Ammonium, yeast

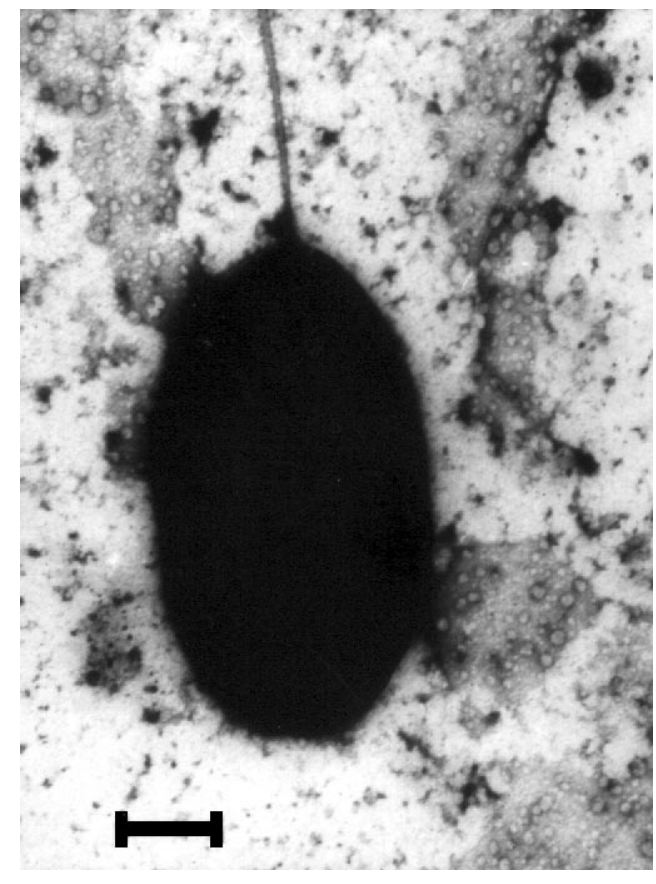

Fig. 1. Electron micrograph of strain $\mathrm{Rb}^{\top}$ showing a single polar flagellum. Bar, $0.2 \mu \mathrm{m}$.

extract, glutamate and molecular nitrogen were used as sole nitrogen sources. Nitrate was reduced to nitrite, which accumulated in the medium. The utilization of thiosulfate was not possible. The $\mathrm{pH}$ range for growth was $5 \cdot 0-8 \cdot 0$ with a $\mathrm{pH}$ optimum of $5 \cdot 5$. Growth was completely inhibited by $1 \%(\mathrm{w} / \mathrm{v}) \mathrm{NaCl}$. $p$-Aminobenzoic acid was required as a growth factor, but could be replaced by $0.05 \%$ yeast extract. Gelatin was not hydrolysed.

\section{Quinones and fatty acids}

Examination of the respiratory lipoquinone content of strain $\mathrm{Rb}^{\mathrm{T}}$ indicated that only ubiquinones were present, and the predominant compound present was ubiquinone 10. These findings are consistent with the placement of this organism in the $\alpha$-subclass of the Proteobacteria (Yokota et al., 1992; Collins \& Jones, 1981; B. J. Tindall, unpublished). The predominant fatty acid was $18: 1 \omega 7 c$, accounting for more than $60 \%$ of the total fatty acids present. The predominance of this fatty acid is also a characteristic feature of members of the $\alpha$-subclass of the Proteobacteria. Differentiation of strain $\mathrm{Rb}^{\mathrm{T}}$ from other taxa and its assignment to the genus Rhodopseudomonas was confirmed by the presence of smaller amounts of $16: 0$,

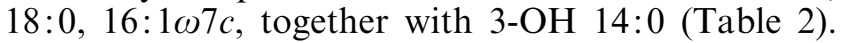
The latter fatty acid was exclusively non-ester linked and is probably amide linked to the lipopolysaccharide, as is the case in Rhodopseudomonas palustris (Weckesser \& Mayer, 1988). The polar lipids comprised diphosphatidyl glycerol, phosphatidyl glycerol, phosphatidyl ethanolamine, phosphatidyl 

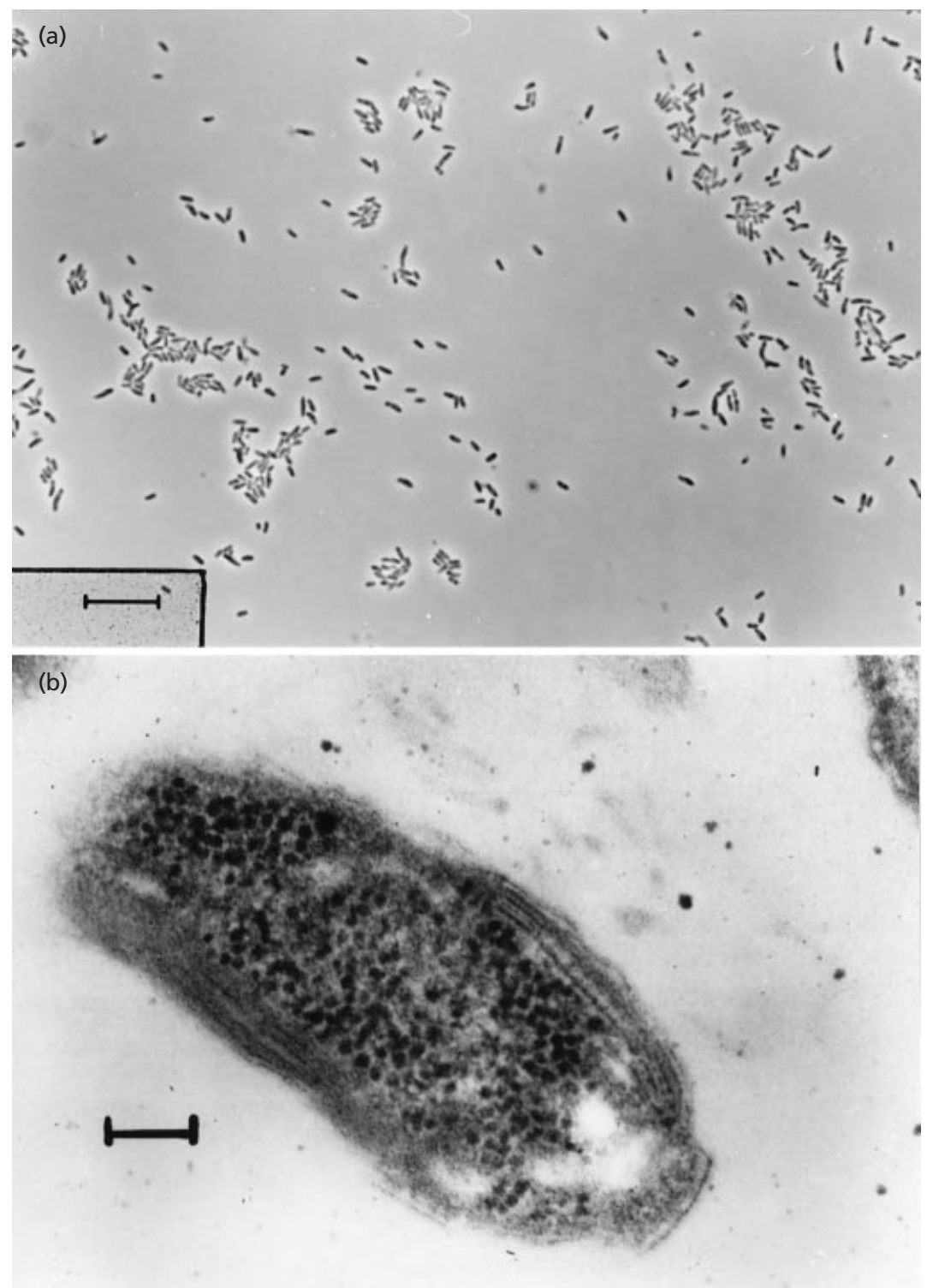

Fig. 2. Cell morphology and ultrastructure of strain $\mathrm{Rb}^{\top}$. (a) Phase-contrast photomicrograph showing general morphology; bar, $10 \mu \mathrm{m}$. (b) Electron micrograph of an ultrathin section showing lamellar ICMs; bar, $0 \cdot 1 \mu \mathrm{m}$.

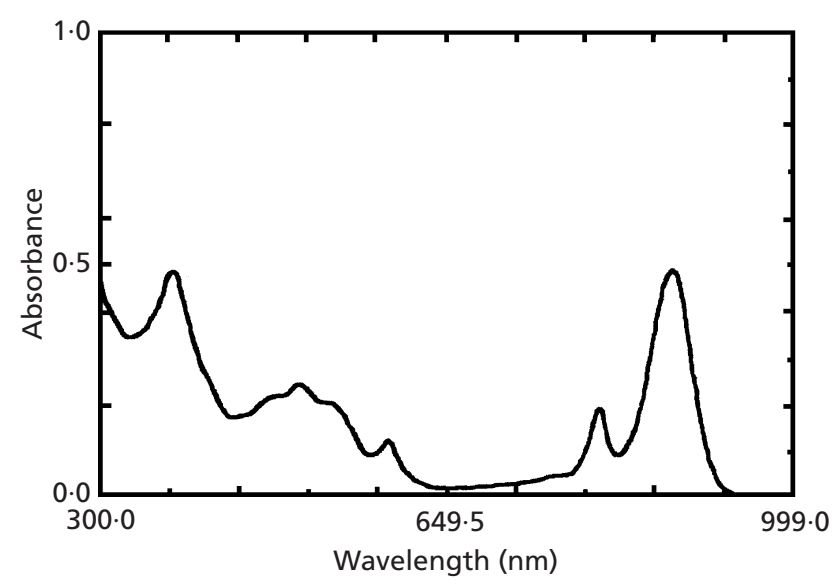

Fig. 3. Absorption spectrum of a cell homogenate of strain $\mathrm{Rb}^{\top}$ grown phototrophically in standard medium. choline and an amino lipid which also stained periodate-Schiff positive. This compound was stable towards both acid and alkali, and was tentatively identified as an amino hopanoid, which has been reported in Rhodopseudomonas palustris (Neunlist et al., 1988), and was detected in the polar lipid fraction of Rhodopseudomonas palustris, with the same $R_{\mathrm{F}}$ value. This polar lipid pattern is characteristic for all members of the Bradyrhizobium-Nitrobacter-AfipiaRhodopseudomonas phyletic group examined to date (B. J. Tindall, unpublished; Moss et al., 1990; Brenner et al., 1991).

\section{DNA base composition}

The $\mathrm{G}+\mathrm{C}$ content of the DNA of strain $\mathrm{Rb}^{\mathrm{T}}$ was $65.4 \pm 0.2 \mathrm{~mol} \%$, which is similar to that of Rhodopseudomonas palustris and Rhodopseudomonas 
Table 1. Differential characteristics of the new isolate $\mathrm{Rb}^{\top}$, Rhodopseudomonas palustris and Rhodopseudomonas acidophila

+ , Good growth; - , no growth; \pm , some strains only; $p$-ABA, $p$-aminobenzoic acid; ND, not done. All species gave positive results for use of acetate, pyruvate, lactate, malate, succinate and fumarate as the electron donor and carbon source. Data for Rhodopseudomonas palustris and Rhodopseudomonas acidophila were obtained from Imhoff \& Trüper (1989).

\begin{tabular}{|lccc|}
\hline Characteristic & Strain Rb & $\begin{array}{c}\text { Rhodopseudomonas } \\
\text { palustris }\end{array}$ & $\begin{array}{c}\text { Rhodopseudomonas } \\
\text { acidophila }\end{array}$ \\
\hline Cell diameter $(\mu \mathrm{m})$ & $0 \cdot 4-0 \cdot 6$ & $0 \cdot 6-0 \cdot 9$ & $1 \cdot 0-1 \cdot 3$ \\
Vitamin(s) required & $p-\mathrm{ABA}$ & $\begin{array}{c}\text { p-ABA } \\
\text { pHotin (some) }\end{array}$ & none \\
pH optimum & $5 \cdot 5$ & $6 \cdot 9$ & $5 \cdot 5-6 \cdot 0$ \\
G+C content $(\mathrm{mol} \%)$ & $65 \cdot 4$ & $64 \cdot 8-66 \cdot 3$ & $62 \cdot 2-66 \cdot 8$ \\
Electron donor and carbon source & & \\
Formate & + & + & \pm \\
Tartrate & + & - & \pm \\
Citrate & - & \pm & \pm \\
Benzoate & - & + & $\mathrm{ND}$ \\
Gluconate & + & $\mathrm{ND}$ & \pm \\
Glucose & - & \pm & - \\
Fructose & - & \pm & \pm \\
Methanol & - & \pm & \pm \\
Ethanol & + & + & + \\
Butyrate $\left(+\mathrm{CO}_{3}^{2-}\right)$ & + & + & - \\
Propionate & - & - & - \\
Arginine & - & + & \\
Glutamate & - & & + \\
\hline
\end{tabular}

Table 2. Fatty acid composition of strain $\mathrm{Rb}^{\top}$

\begin{tabular}{|lcc|}
\hline Fatty acid & $\begin{array}{r}\text { Method 1 } \\
\text { area }(\%)\end{array}$ & $\begin{array}{r}\text { Method 2 } \\
\text { area (\%) }\end{array}$ \\
\hline $3-\mathrm{OH} 14: 0$ & $0 \cdot 00$ & $1 \cdot 47$ \\
$\mathrm{~A}^{*}$ & $0 \cdot 38$ & $0 \cdot 30$ \\
$16: 1 \omega 7 c$ & $9 \cdot 47$ & $8 \cdot 53$ \\
$16: 0$ & $11 \cdot 74$ & $11 \cdot 38$ \\
$i-17: 0$ & $0 \cdot 63$ & $0 \cdot 60$ \\
$\mathrm{~B}^{*}$ & $0 \cdot 44$ & $0 \cdot 62$ \\
$\mathrm{C}^{* \dagger}$ & $0 \cdot 93$ & $1 \cdot 52$ \\
$18: 1 \omega 7 c$ & $66 \cdot 06$ & $66 \cdot 14$ \\
$18: 0$ & $7 \cdot 83$ & $8 \cdot 43$ \\
methyl-18: $1 \omega 12$ & $2 \cdot 53$ & $2 \cdot 49$ \\
\hline
\end{tabular}

* Compounds not unambiguously identified.

$\uparrow$ Compound $\mathrm{C}$ does not appear to be a fatty acid. The use of a differential hydrolysis (method 1 vs method 2) of the fatty acids indicates that the 3-OH 14:0 fatty acid is not ester-linked, and is probably amide-bound.

acidophila and slightly higher than the $\mathrm{G}+\mathrm{C}$ content of Rhodopseudomonas julia $(63.5 \mathrm{~mol} \%)$.

\section{Genetic relationships}

The sequence of two fragments of the 16S rRNA gene from strain $\mathrm{Rb}^{\mathrm{T}}$ corresponding to position $36-487$ and
566-1236, respectively (E. coli numbering), was determined. The deduced 16S rRNA molecule exhibited nucleotide deletions of 11 bases in the loop structure at position 201-215. This feature is characteristic for species belonging to the $\alpha$-subclass of the Proteobacteria (Woese, 1987). The sequence of strain $\mathrm{Rb}^{\mathrm{T}}$ was compared with the sequences from representative species of phototrophs and their non-phototrophic relatives of the $\alpha$-subclass of the Proteobacteria. Strain $\mathrm{Rb}^{\mathrm{T}}$ was closely related to Bradyrhizobium japonicum, Nitrobacter winogradskyi and Rhodopseudomonas palustris at a similarity level of $96-98 \%$ but showed much lower affinities to all other members of the purple non-sulfur bacteria $(<93 \%$ similarity, data not shown). On the basis of the corrected distance values a neighbour-joining tree was constructed (Fig. 4). Strain $\mathrm{Rb}^{\mathrm{T}}$, Rhodopseudomonas palustris, Bradyrhizobium japonicum and $N$. winogradskyi formed a tight cluster distinct from Rhodopseudomonas acidophila and all other purple non-sulfur bacteria investigated. The monophyletic nature of this cluster was supported by bootstrapping in $100 \%$ of the 1000 trees generated. The level of DNA-DNA hybridization with the only other purple non-sulfur bacterium in this cluster, Rhodopseudomonas palustris DSM 123, was $37.5 \%$. This low level of genomic DNA relatedness supports the differentiation of the two strains at the species level, supporting the results of the physiological tests. 


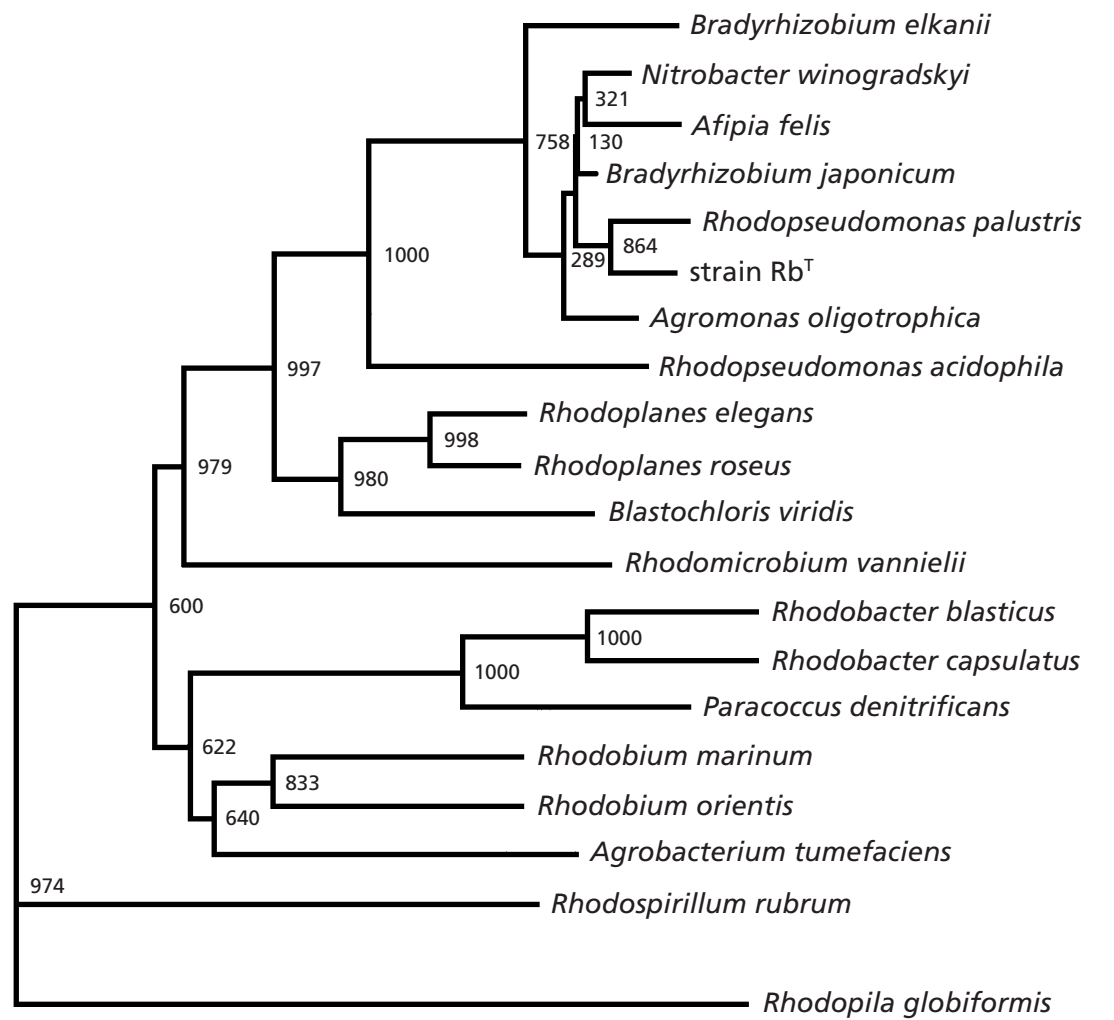

Fig. 4. Distance matrix tree showing phylogenetic relationships between the new isolate and related organisms belonging to the $\alpha$-subclass of the Proteobacteria. Bootstrap confidence values obtained from 1000 bootstrap trials are given at branch points.

\section{DISCUSSION}

In recent years the unsatisfactory taxonomy of the genus Rhodopseudomonas was clarified on the basis of 16S rRNA sequence analysis, and phenotypic and chemotaxonomic data. The consequence was that a number of new genera, like Rhodobium, Blastochloris and Rhodoplanes (Hiraishi \& Ueda, 1994; Hiraishi et al., 1995) were created. It was suggested by Hiraishi (1997) that only the type species Rhodopseudomonas palustris should remain in the genus Rhodopseudomonas. To date the genus Rhodopseudomonas comprises the species Rhodopseudomonas palustris, Rhodopseudomonas acidophila and Rhodopseudomonas julia.

The results of our experiments show that the new isolate is facultatively photoheterotrophic, multiplies by budding and possesses ICM of the lamellar type with bacteriochlorophyll $a$ and carotenoids of the spirilloxanthin series. Among species with these features our isolate resembles most closely Rhodopseudomonas palustris. However, a characteristic feature of Rhodopseudomonas palustris, the utilization of benzoate, is not shown by our isolate. The optimum $\mathrm{pH}$ for growth also differs between the two strains. The inability of strain $\mathrm{Rb}^{\mathrm{T}}$ to utilize benzoate could be due to the lack of only a few enzymes, but the optimal growth at $\mathrm{pH} 5 \cdot 5$ seems to be a more complex feature. Our isolate resembles Rhodopseudomonas acidophila with respect to the optimum $\mathrm{pH}$ for growth, but differs in size, vitamin requirement and carbon utilization. The 16S rDNA analysis confirms these results showing that Rhodopseudomonas palustris and strain $\mathrm{Rb}^{\mathrm{T}}$ form a tight cluster together with Bradyrhizobium japonicum and $N$. winogradskyi, which is clearly separated from Rhodopseudomonas acidophila and all other members of the purple non-sulfur bacteria. The result of the DNA-DNA hybridization between strain $\mathrm{Rb}^{\mathrm{T}}$ and Rhodopseudomonas palustris differentiates them at the species level, supporting the phenotypic differences.

The chemical composition of strain $\mathrm{Rb}^{\mathrm{T}}$ also shows a number of features in common with members of the genera Afipia, Bradyrhizobium and Nitrobacter, as well as the species Rhodopseudomonas palustris and Blastobacter denitrificans (B. J. Tindall, unpublished; Moss et al., 1990; Brenner et al., 1991; Yokota \& Sakane, 1991; Urakami \& Komagata, 1988). Although all organisms share the presence of ubiquinone 10 as the major respiratory lipoquinone, together with $18: 1 \omega 7 c$ dominating in the fatty acids, these are features characteristic of the majority of taxa within the $\alpha$-subclass of the Proteobacteria. The presence of the four phospholipids phosphatidyl glycerol, phosphatidyl choline, phosphatidyl ethanolamine and diphosphatidyl glycerol, together with the presence of an amino hopanoid distinguishes this phyletic group of organisms (B. J. Tindall, unpublished) and further reinforces their monophyletic origin. Despite the fact that all these organisms are very similar in their chemical composition, both strain $\mathrm{Rb}^{\mathrm{T}}$ and Rhodopseudomonas palustris share the presence of an exclusively amino linked 3-OH 14:0 fatty acid. In 
contrast, published data on members of the genus Bradyrhizobium indicate that 3-OH 12:0 and 3-OH 14:0 are present (Yokota \& Sakane, 1991), whereas significant quantities of 3-OH fatty acids have not been detected in members of the genus Afipia (Moss et al., 1990; Brenner et al., 1991). Taken together with the ability of both organisms to grow phototrophically under anaerobic conditions, we consider these two species to constitute a distinct genus, rather than placing all members of this phyletic group in a single genus, for which the name Nitrobacter has priority. Considering that Rhodopseudomonas palustris is the type species of the genus Rhodopseudomonas, we propose that strain $\mathrm{Rb}^{\mathrm{T}}$ be included in this genus as a new species, for which we propose the name Rhodopseudomonas rhenobacensis $\mathrm{sp}$. nov. The question of the taxonomic position of other members of the genus Rhodopseudomonas is outside the scope of the present work.

\section{Description of Rhodopseudomonas rhenobacensis sp. nov.}

Rhodopseudomonas rhenobacensis (rhe.no.ba.cen'sis. M.L. adj. rhenobacensis pertaining to Rheinbach, a small city near Bonn, Germany, the origin of the isolate).

Cells are rods, 0.4-0.6 $\mu \mathrm{m}$ wide and 1.5-2.0 $\mu \mathrm{m}$ long. Cells multiply by budding and are motile by means of flagella. Rosette formation is found in older cultures. ICMs are of the lamellar type. Absorption maxima of cell extracts are at 376, 471, 503, 540, 591, 805 and $878 \mathrm{~nm}$. The optimum $\mathrm{pH}$ for growth is 5.5. $p$ Aminobenzoic acid is required as growth factor but can be replaced by $0.05 \%$ yeast extract. Facultative phototrophs growing anaerobically in the light or aerobically in the darkness. Carbon sources for phototrophic growth are formate, acetate, pyruvate, lactate, malate, succinate, fumarate, tartrate, gluconate, ethanol and butyrate ( + carbonate). No growth occurs with citrate, benzoate, glucose, fructose, methanol, propionate, arginine and glutamate. Nitrogen sources are $\mathrm{N}_{2}$, ammonia, glutamate or yeast extract. The predominant quinone is ubiquinone 10 . The $\mathrm{G}+\mathrm{C}$ content of the DNA is $65 \cdot 4 \pm 0 \cdot 2 \mathrm{~mol} \%$. Isolated from freshwater lake sediment. The type strain is $\mathrm{Rb}^{\mathrm{T}}$ (= DSMZ 12706 ${ }^{\mathrm{T}}$ ).

\section{REFERENCES}

Biebl, H. \& Drews, G. (1969). Das in-vivo-Spektrum als taxonomisches Merkmal bei Untersuchungen zur Verbreitung von Athiorhodaceae. Zentbl Bakteriol Parasitenkd Infektionskr Hyg Abt II Orig 123, 425-452.

Brenner, D. J., Hollis, D. G., Moss, C. W. \& 25 other authors (1991). Proposal of Afipia gen. nov., with Afipia felis sp. nov. (formerly cat scratch disease bacillus), Afipia clevelandensis sp. nov. (formerly the Cleveland Clinic Foundation strain), Afipia broomae sp. nov., and three unnamed genospecies. J Clin Microbiol 29, 2450-2460.

Cashion, P., Holder-Franklin, M. A., McCully, J. \& Franklin, M.
(1977). A rapid method for the base ratio determination of bacterial DNA. Anal Biochem 81, 461-466.

Collins, M. D. \& Jones, D. (1981). Distribution of isoprenoid quinone structural types in bacteria and their taxonomic implications. Microbiol Rev 45, 316-354.

De Ley, J., Cattoir, H. \& Reynaerts, A. (1970). The quantitative measurement of DNA hybridization from renaturation rates. Eur J Biochem 12, 133-142.

Hiraishi, A. \& Ueda, Y. (1994). Rhodoplanes gen. nov., a new genus of phototrophic bacteria including Rhodopseudomonas rosea as Rhodoplanes roseus comb. nov. and Rhodoplanes elegans sp. nov. Int J Syst Bacteriol 44, 665-673.

Hiraishi, A., Urata, K. \& Satoh, T. (1995). A new genus of marine budding phototrophic bacteria, Rhodobium gen. nov., which includes Rhodobium orientis sp. nov. and Rhodobium marinum comb. nov. Int J Syst Bacteriol 45, 226-234.

Hiraishi, A. (1997). Transfer of the bacteriochlorophyll $b$ containing phototrophic bacteria Rhodopseudomonas viridis and Rhodopseudomonas sulfoviridis to the genus Blastochloris gen. nov. Int J Syst Bacteriol 47, 217-219.

Hougardy, A. \& Klemme, J.-H. (1995). Nitrate reduction in a new strain of Rhodoferax fermentans. Arch Microbiol 164, 358-362.

Imhoff, J. F. \& Trüper, H. G. (1989). Purple nonsulfur bacteria. In Bergey's Manual of Systematic Bacteriology, vol. 3, pp. 1658-1682. Edited by J. T. Staley, M. P. Bryant, N. Pfennig \& J. G. Holt. Baltimore: Williams \& Wilkins.

Imhoff, J. F. \& Trüper, H. G. (1991). The genus Rhodospirillum and related genera. In The Prokaryotes, vol. 3, pp. 2141-2155. Baltimore: Springer.

Kern, M., Koch, H. G. \& Klemme, J.-H. (1992). EDTA activation of $\mathrm{H}_{2}$ photoproduction by Rhodospirillum rubrum. Appl Microbiol Biotechnol 37, 496-500.

Moss, C. W., Holzer, G., Wallace, P. L. \& Hollis, D. G. (1990). Cellular fatty acid compositions of an unidentified organism and a bacterium associated with cat scratch disease. J Clin Microbiol 28, 1071-1074.

Neunlist, S., Bisseret, P. \& Rohmer, M. (1988). The hopanoids of the purple non-sulphur bacteria Rhodopseudomonas palustris and Rhodopseudomonas acidophila and the absolute configuration of bacteriohopanetetrol. Eur J Biochem 171, 245-252.

Nicholas, D. J. D. \& Nason, A. (1957). Determination of nitrate and nitrite. Methods Enzymol 3, 981-984.

Nichols, P. D., Guckert, J. B. \& White, D. C. (1986). Determination of monounsaturated fatty acid double-bond position and geometry for microbial monocultures and complex consortia by capillary GC-MS of their dimethyl disulphide adducts. $J$ Microbiol Methods 5, 49-55.

Stahl, E. (1967). Dünnschichtchromatographie. Berlin: Springer.

Thompson, J. D., Higgins, D. G. \& Gibson, T. J. (1994). CLUSTAL $\mathrm{W}$ : improving the sensitivity of progressive multiple sequence alignment through sequence weighting, positions-specific gappenalties and weight matrix choice. Nucleic Acids Res 22, 4673-4680.

Tindall, B. J. (1990a). A comparative study of the lipid composition of Halobacterium saccharovorum from various sources. Syst Appl Microbiol 13, 128-130.

Tindall, B. J. (1990b). Lipid composition of Halobacterium lacusprofundi. FEMS Microbiol Lett 66, 199-202.

Urakami, T. \& Komagata, K. (1988). Cellular fatty acid composition with special reference to the existence of hydroxy fatty acids and the occurrence of squalene and sterols in species of 
Rhodospirillaceae genera and Erythrobacter longus. J Gen Appl Microbiol 34, 67-84.

Visuvanathan, S. (1989). Simple enzymatic method for isolation of DNA from diverse bacteria. J Microbiol Methods 10, 59-64.

Weaver, P. F., Wall, J. D. \& Gest, H. (1975). Characterization of Rhodopseudomonas capsulata. Arch Microbiol 105, 207-216.

Weckesser, J. \& Mayer, H. (1988). Different lipid A types in lipopolysaccharides of phototrophic and related non-phototrophic bacteria. FEMS Microbiol Rev 54, 143-154.
Woese, C. R. (1987). Bacterial evolution. Microbiol Rev 51, 221-271.

Yokota, A. \& Sakane, T. (1991). Taxonomic significance of fatty acid compositions in whole cells and lipopolysaccharides in Rhizobiaceae. IFO Res Commun 15, 57-75.

Yokota, A., Akagawa-Matusushita, M., Hiraishi, A., Katayama, Y., Urakami, T. \& Yamasato, K. (1992). Distribution of quinone systems in microorganisms: Gram-negative eubacteria. Bull JFCC 8, 136-171. 